\title{
A Case Control Study of The Role of N-Terminal Pro Brain Natriuretic Peptide in Diagnosing Heart Failure
}

\author{
Dr. Chaudhari Sandip Tarachand ${ }^{1}$,Dr. Pranav Shende ${ }^{2}$,Dr. Aniket C. Pawar ${ }^{3}$, \\ ${ }^{1}$ Assistant Professor, ${ }^{2}$ Postgraduate Student, ${ }^{3}$ Postgraduate Student \\ Department Of Medicine, Dr Vasantrao Pawar Medical College \& Research Centre, Nashik
}

\begin{abstract}
Introduction: Brain natriuretic peptides are released from the ventricles in response to volume overload or pressure overload. This case control study was performed to understand the role of plasma N-Terminal pro Brain Natriuretic peptide (N-TproBNP) in diagnosing $H F$.

Methodology: We included 32 patients with clinical features of cardiac failure who presented to the outpatient clinic of Department of Medicine and Emergency Department of Yashoda Hospital, Hyderabad between November 2005 to October 2007 and equal number of age and sex matched healthy. We obtained clinical history of the patient and plasma sample to measure N-T pro BNP.

Rresults:Average $\mathrm{N}-T$ pro BNP in cases was $3179 \mathrm{pg} / \mathrm{ml}$ and in controls was $103 \mathrm{pg} / \mathrm{ml}$. Majority of the patients had long standing hypertension and ischemic cardiomyopathy was the commonest cause of HF in our patient population. Mean N-T pro BNP was found to be higher in females $(3481 \mathrm{pg} / \mathrm{mL})$ as compared to males $(2934$ $\mathrm{pg} / \mathrm{mL}$ ). Systolic dysfunction $(3316 \mathrm{pg} / \mathrm{mL})$ raised the $N$-T pro BNP more than diastolic dysfunction. Higher the degree of HF according to New York Heart Association classification was associated with higher N-T pro BNP using competitive enzyme immunoassay technique. Collected data was analysed using appropriate statistical tests.

Conclusions: This study showed that plasma N-T pro BNP can be taken as a good marker for the diagnosis of cardiac failure in emergency setting. Future research should focus on the prognostic value of plasma $N-T$ pro BNP.
\end{abstract}

\section{Introduction}

The worldwide magnitude of the heart failure (HF) problem cannot be assessed with precision since reliable, population-based estimates of its prevalence, incidence, and prognosis are lacking for many regions of the globe, and a variety of methods that include history, physical examination, and heart function have been used to diagnose the condition. There are an estimated 23 million people with HF worldwide. Thus, it is anticipated that the problem of HF will nearly double over the next thirty to forty years. Aging of the population and prolongation of the lives of cardiac patients by modern therapeutic innovations has led to an increasing prevalence of heart failure (HF). Despite improvements in therapy, the mortality rate in patients with HF has remained unacceptably high, making early detection of susceptible persons who would benefit from preventive measures imperative.

Diagnosing HF often can be extremely difficult and both over diagnosis and under diagnosis are common. This is true especially in the elderly population, obese individuals and in patients with an underlying lung disease. Echocardiogram is useful to detect the presence of systolic dysfunction. However, studies have shown that $50 \%$ of patients with well established clinical HF have normal systolic function (diastolic HF). Further more, $50 \%$ patients with systolic dysfunction have no symptoms of HF. Brain natriuretic peptides are released from the ventricles in response to volume overload or pressure overload physiologically and they function to counteract renin angiotensin system, cause vasodilatation and natriuresis. This study was performed to investigate the performance of a novel assay for plasma N-Terminal pro Brain Natriuretic peptide $(\mathrm{N}$ TproBNP) in diagnosing HF, to correlate the levels of plasma N-Terminal pro Brain Natriuretic peptide with the severity of HF and to correlate the levels of plasma N-Terminal pro Brain Natriuretic peptide with systolic and diastolic dysfunction.

\section{Study Design and Setting}

II. Methodology

For this prospective case controlled study we included 32 patients with clinical features of cardiac failure who presented to the outpatient clinic of Department of Medicine and Emergency Department of Yashoda Hospital, Hyderabad between November 2005 to October 2007 and equal number of age and sex matched healthy controls were included. The study was performed according to the prescribed guidelines provided by the Indian Council of Medical Research, New Delhi. Yashoda Hospital, Hyderabad is a major 
healthcare provider and a teaching hospital in the region with a combined capacity of over 1200 beds. Hyderabad is the capital of the Indian state of Telangana and the fourth most populous city in the country, with an estimated population of 9 million. Sex ratio of the city is 945 females per 1000 males with an average literacy at $83 \%$.

\section{Sample population}

We included patients who presented with clinical features of heart failure as per Framinghams criteria.The criteria is used for the diagnosis of congestive heart failure. Major criteria includes Rales, Cardiomegaly, Acute Pulmonary oedema, Third heart sound, Paroxysmal Nocturnal Dyspnea, Neck vein distension, Increased Venous pressure (>16 Cm of H2O), Circulation time $>25 \mathrm{Sec}$ and Positive Hepatojugular reflux. Minor criteria includes Night Cough, Dyspnea on exertion, Hepatomegaly, Pleural effusion, Ankle oedema, Tachycardia (rate of $>120 / \mathrm{min}$ ) and Vital Capacity - decreased 1/3 from normal. For the clinical diagnosis at least 1 major \& 2 Minor criteria are required. We excluded patients who were aged less than 15 years, had sepsis, pulmonary disease or renal failure

\section{Data Collection and Data Analysis}

After obtianing approval of the ethical committee, detailed clinical history was recorded regarding age, duration of symptoms, ischemic heart disease, rheumatic heart disease, hypertension, diabetes, dyslipidemias, smoking, alcoholism. All patients underwent complete clinical examination including examination of pulse, blood pressure, respiratory system, cardiovascular system and central nervous system.Biochemical investigations including random blood sugar, blood urea, complete blood picture, serum creatinine and electrolytes done. ECG, chest $\mathrm{x}$ ray, 2D echocardiogram and ultrasound abdomen was done for every case and control subject.In subjects with clinical features of heart failure and in healthy controls, $2 \mathrm{ml}$ of blood sample is drawn for assay of plasma N-Terminal pro Brain Natriuretic peptide within half an hour of presentation. Using bio medical kit plasma N-T pro BNP concentration is measured.The kit is a competitive enzyme immunoassay designed to measure the immuno reactive N-T pro BNP. Detectability range by this method of N-TproBNP is 5 $\mathrm{pg} / \mathrm{ml}$ to $35,000 \mathrm{pg} / \mathrm{ml}$. Collected data was compiled and entered in microsoft excel sheets. Using Epi Info statistical software, we analyzed the data using appropriate statistical tests.

\section{Results}

We included 32 cases and controls each. As shown in Table 1 both the groups were comparable in terms of average age and gender distribution. Average N-T pro BNP in cases was $3179 \mathrm{pg} / \mathrm{ml}$ and in controls was $103 \mathrm{pg} / \mathrm{ml}$. Majority of the patients had long standing hypertension and coronary artery disease (Table 2). Ischemic cardiomyopathy was the commonest cause of $\mathrm{HF}$ in our patient population. Rheumatic heart disease and dilated cardiomyopathy were other common causes of HF in our patients. Cardiomegaly was seen as the most common clinical presentation in our patients. Pedal edema and raised jugular venous pressure were other common clinical presentations (Table 2). Mean N-T pro BNP was found to be higher in females as compared to males (Table 3). Systolic dysfunction raised the N-T pro BNP more than diastolic dysfunction. We also found that higher the degree of HF according to New York Heart Association classification higher was the N-T pro BNP.

\section{Discussion}

Brain natriuretic peptide (BNP) is a hormone which was initially identified in the brain but later was found to be released mainly from the heart, particularly the ventricles. Volume expansion results in the release of Atrial natriuretic peptide (ANP) fromthe myocardial cells in the atria and in some cases the ventricles and from possibly increased wall stress. HF results in the increased release of both ANP and BNP, as ventricular cells are recruited to secrete both ANP and BNP in response to the high ventricular filling pressures. Normally the circulating concentration of BNP is less than $20 \%$ of that of, but can equal or exceed that of ANP in patients with HF; this wider range of concentrations makes measurement of BNP more useful than ANP in evaluation of patients with HF.Not all patients with symptomatic HF have high plasma BNP concentrations and not all asymptomatic patients have low values. This was demonstrated in a review of 558 consecutive ambulatory patients with treated stable HF in a specialized outpatient HF clinic.

The role of N-T pro BNP is illustrated from a retrospective cohort study that compared the differences in plasma NT-proBNP among 1256 patients with and without acute HF. The study found that the optimal value for distinguishing HF from other causes of dyspnea varied with patient age. For patients $<50,50$ to 75 , and $>75$ years of age, the optimal plasma NT-proBNP cutoffs for diagnosing HF were $450 \mathrm{pg} / \mathrm{mL}, 900 \mathrm{pg} / \mathrm{mL}$, and 1800 $\mathrm{pg} / \mathrm{mL}$ respectively. Overall, these cutoffs yielded a sensitivity and specificity of 90 and 84 percent, respectively.In addition, the concentration of NT-proBNP is elevated in the pleural fluid in patients with HF and a pleural effusion and may therefore be of some value in the diagnosis of pleural effusion. 
Increased plasma BNP can indicate the presence of HF due to diastolic dysfunction with similar accuracy to systolic dysfunction. Studies show that the values do not differentiate between systolic and diastolic dysfunction. However, our dataset showed higher BNP values for systolic dysfunction. The study done by Prontera et al showed the similar result with N-T pro BNP increasing with the increasing functional severity of heart failure. Another study by James et al, the international collaborative of N-T pro BNP study, showed that with the increase in the severity of cardiac failure, NT Pro BNP increases.

Plasma NT-proBNP, additionally, correlates well with prognosis in patients with acute and chronic HF. In a subgroup of 1011 patients in the COPERNICUS study, the median baseline NT-proBNP concentration was $1767 \mathrm{pg} / \mathrm{mL}$. All-cause mortality at one year was significantly higher for patients with a plasma NT-proBNP above the median, compared to levels below the median (22\% versus $7 \%$, risk ratio 2.7$)$. A similar increase was found in the combined end point of all-cause mortality or hospitalization for HF (38\% versus $19 \%$, risk ratio 2.4). Similar observations were made in the Australia/New Zealand Heart Failure trial.

\section{Conclusion}

This study showed that plasma measurements of N-T pro BNP can be taken as a good marker for the diagnosis of cardiac failure in emergency setting where one is not sure regarding the cause of dyspnea, whether respiratory(bronchial asthma, COPD) or cardiac origin. Also one can know the functional severity of cardiac failure objectively and also predict whether systolic or diastolic dysfunction is the cause of cardiac failure.

Table 1 Description of cases and controls

\begin{tabular}{|l|l|l|}
\hline \multicolumn{1}{|c|}{ Cases } & Controls \\
\hline Sample & 32 & 32 \\
\hline Average age and range (years) & $50.9(22-74)$ & $51.5(24-72)$ \\
\hline Males & 18 & 18 \\
\hline $\begin{array}{l}\text { Mean N-terminal pro b-type natriuretic peptide } \\
(\mathrm{pg} / \mathrm{mL})\end{array}$ & $3179(564-8428)$ & $103(64-186)$ \\
\hline
\end{tabular}

Table 2. Clinical description of cases

\begin{tabular}{|l|l|}
\hline Risk factors present & 14 \\
\hline Hypertension & 7 \\
\hline Diabetes mellitus & 12 \\
\hline Coronary artery disease & 7 \\
\hline Smoking & 13 \\
\hline Causes of Heart failure & 6 \\
\hline Ischemic cardiomyopathy & 4 \\
\hline Rheumatic heart disease & 9 \\
\hline Dilated cardiomyopathy & \multicolumn{2}{|l|}{} \\
\hline Others (hypertension, diastolic dysfunction) & 16 \\
\hline Clinical features & 7 \\
\hline Pedal edema & 13 \\
\hline Third heart sound & 25 \\
\hline Raised jugular venous pressure & 11 \\
\hline Cardiomegaly & \\
\hline Hepatomegaly & \\
\hline
\end{tabular}

Table 3. Mean N-terminal pro b-type natriuretic peptide levels in patients

\begin{tabular}{|l|l|}
\hline Variables under study & Mean level (pg/mL) \\
\hline According to gender & 2943 \\
\hline Males & 3481 \\
\hline Females & 3316 \\
\hline According to type of failure & 1963.6 \\
\hline Systolic dysfunction & 4552 \\
\hline Diastolic dysfunction & 2459 \\
\hline According to ejection fraction & 766 \\
\hline Less than 40\% & 1380 \\
\hline More than 40\% & 1926.8 \\
\hline According to New York Heart Association classification \\
\hline Class I & 3928 \\
\hline Class II & \\
\hline Class III & \\
\hline Class IV & \\
\hline
\end{tabular}




\section{References}

[1]. Hoes AW, Mosterd A, Grobbee DE. An epidemic of heart failure? Recent evidence from Europe. Eur Heart J $1998 ; 19$ Suppl L:L2.

[2]. Ho KK, Pinsky JL, Kannel WB, Levy D, Pitt B. The epidemiology of heart failure: the Framingham Study. Journal of the American College of Cardiology. 1993;22(4s1):A6-13.

[3]. The Criteria Committee of the New York Heart Association. Nomenclature and Criteria for diagnosis. 9th ed. Boston:Little, Brown ,1994.

[4]. Aurigemma GP. Diastolic heart failure - a common and lethal condition by any name. New England Journal of Medicine. 2006;355(3):308-10.

[5]. Mukoyama M, Nakao K, Hosoda K, et al. Brain natriuretic peptide as a novel cardiac hormone in humans. J Clin Invest . 1991;87:1402-12

[6]. Urban Agglomerations/Cities having population 1 lakh and above. Census of India website.

[7]. http://www.censusindia.gov.in/2011-prov-results/paper2/data_files/India2/Table_3_PR_UA_Citiees_1Lakh_and_Above.pdf

[8]. accessed Decemeber 28, 2015

[9]. Iwanaga Y, Nishi I, Furuichi S, et al. B-type natriuretic peptide strongly reflects diastolic wall stress in patients with chronic heart failure: comparison between systolic and diastolic heart failure. J Am Coll Cardiol 2006; 47:742.

[10]. Kinnunen P, Vuolteenaho O, Ruskoaho H. Mechanisms of atrial and brain natriuretic peptide release from rat ventricular myocardium: effect of stretching. Endocrinology 1993; 132:1961.

[11]. Tang WH, Girod JP, Lee MJ, et al. Plasma B-type natriuretic peptide levels in ambulatory patients with established chronic symptomatic systolic heart failure. Circulation 2003; 108:2964.

[12]. Januzzi JL, van Kimmenade R, Lainchbury J, et al. NT-proBNP testing for diagnosis and short-term prognosis in acute destabilized heart failure: an international pooled analysis of 1256 patients: the International Collaborative of NT-proBNP Study. Eur Heart J $2006 ; 27: 330$.

[13]. Krishnaswamy P, Lubien E, Clopton P, et al. Utility of B-natriuretic peptide levels in identifying patients with left ventricular systolic or diastolic dysfunction. Am J Med 2001; 111:274.

[14]. Prontera C, Emdin M, Zucchelli GC, Ripoli A, Passino C, Clerico A Natriuretic peptides (NPs): automated electrochemiluminescent immunoassay for N-terminal pro-BNP compared with IRMAs for ANP and BNP in heart failure patients and healthy individuals. Clinical chemistry. 2003;49(9):1552-4.

[15]. Januzzi JL, Van Kimmenade R, Lainchbury J, Bayes-Genis A, Ordonez-Llanos J, Santalo-Bel M, Pinto YM, Richards M. NTproBNP testing for diagnosis and short-term prognosis in acute destabilized heart failure: an international pooled analysis of 1256 patients. European heart journal. 2006;27(3):330-7.

[16]. Richards AM, Doughty R, Nicholls MG, Macmahon S, Ikram H, Sharpe N, Espiner EA, Frampton C, Yandle TG. Neurohumoral prediction of benefit from carvedilol in ischemic left ventricular dysfunction. Circulation. 1999;99(6):786-92.

[17]. Hartmann F, Packer M, Coats AJ, et al. Prognostic impact of plasma N-terminal pro-brain natriuretic peptide in severe chronic congestive heart failure: a substudy of the Carvedilol Prospective Randomized Cumulative Survival (COPERNICUS) trial. Circulation 2004; 110:1780.

[18]. Richards AM, Doughty R, Nicholls MG, et al. Plasma N-terminal pro-brain natriuretic peptide and adrenomedullin: prognostic utility and prediction of benefit from carvedilol in chronic ischemic left ventricular dysfunction. Australia-New Zealand Heart Failure Group. J Am Coll Cardiol 2001; 37:1781. 